\title{
Claudel \& Rodin Fateful Encounter or La rencontre de deux destins: a one point perspective (2006)
}

\author{
Louise R. Witherell
}

I borrow the words "one point perspective" from a much admired supporter of woman's art in the United States: Elsa Honig Fine, the creator and publisher of the Woman's Art Joumal. During approximately 25 years, each issue of her magazine was begun under this title giving her own assessment of its contents. I have not had Mme Fine's training nor her breadth of experience in art criticism, nor do I have her skill in presenting pithy introductions to the work at hand. But she encouraged my early considerations of the life and work of Camille Claudel. Elsa Fine edited sparingly but wisely what I wrote, permitting a literary type to be published in her pages. I believe that my general summary of what was known about the life and work of Camille Claudel in the mid 1980's was the first such item to be published in the United States (see Woman's Art Journal, Summer 1985, Witherell, "Camille Claudel Rediscovered," 1-7.) This was, of course, soon followed by other articles in various places, including the Smithsonian.

So how did I come to my own point of view as a firm believer in the genius of Camille Claudel? Rather slowly and almost accidentally.

I began by doing research on and then translating some of Paul Claudel's early plays. I frequently attended the Rencontres claudéliennes from 1972 on. These were held at the château which Paul had bought near the small town of Brangues in southeastern France. Many of Camille Claudel's sculptures were simply part of the furnishings in the château. They compelled my attention from my first sight of them.

Although I did not study art as a university scholar would, I began as a child—probably around 1930-to spend every 
Saturday morning of the school year taking art lessons and music appreciation sessions at the Toledo (Ohio) Museum of Art. Bless that beautiful place: they welcomed children, even those unaccompanied by adults. (Of course, they had to have increased security.) Museums became for me a sort of second home because of my being welcomed into training there for several years. Among many things which I learned were the basic skills of the graphic arts, including how to make a small clay statue of a seated, naked woman. I never had illusions of becoming an accomplished artist myself, but I certainly can still feel in my physical self what specific efforts artists must make in order to create their works.

The combination of my childhood training in art with my viewing of sculptures by Camille Claudel in what became the Claudel family home in Brangues made me feel comfortable about writing my early American article about her life and work. The attached footnotes bear witness to the thoroughness which can be achieved far from France.

When the 1988 exhibit of Camille Claudel's work came from France to Japan and then to Washington, D.C., I was invited to give one of the two initial lectures there at the relatively new National Museum of Women in the Arts. In answer to the Museum's request, I prepared a paper accompanied by slides and musical recordings: "Camille Claudel: Muse and InspirationAuguste Rodin, Claude Debussy, and Paul Claudel."

At the present time, of course, I find myself in the body of an old lady. My health is failing more than I like. Imagine my excitement and frustration when I first learned that a new exhibit (2005) had been put together by a mix of older and younger international art critics, curators and such-an exhibit especially focused on the genius and originality of Camille Claudel when she was doing her work beside Auguste Rodin. Alas, I could not go to see the exhibit because I was too fragile to travel to it, even though it would come to Detroit, Michigan, not far from my home town of Toledo, Ohio, nor even far from my new "rest home" establishment in Milwaukee, Wisconsin. 
Friends sent me first a copy of the exhibit's catalogue in English, which I supplemented later with a copy of the catalogue in French, obtained from Québec's Musée national des beaux-arts.

The exhibit, shown first in Québec, then in the Detroit Institute of Arts, was to finish by June 15, 2006-a little more than a year after it began, ending in Marigny, Switzerland, at the Fondation Pierre Ganadda. This touring exhibit did not seem to me (in the Midwest) to be widely publicized. However, everyone I knew who saw it was deeply impressed by the thoroughness of its presentation. I hope that those who did not make it to the exhibit itself will take this present point of perspective summary as reason to study the catalogues in depth. Much gold can be found in them!

The catalogue contains a unique collection of new assessments of the work produced by Camille Claudel and Auguste Rodin-articles written by both relatively new commentators and some longer established authoritative critics of the work of both artists. Names of the authors-some of whom have written more than one entry-are: Odile Ayral-Clause, Catherine Chevillot, Bruno Gaudichon, Véronique Gautherin, Yves Lacasse, Antoinette Le Normand-Romain, Laure de Margerie, Raphaël Masson, Marie-Victoire Nantet, Jean-Michel Nectoux, Line Ouellet, John R. Porter, Anne Rivière, and Jacques Vilain (4). Jointly published in 2005 by the Musée national des beaux-arts du Québec and the Musée Rodin in Paris. The total text, which one must presume was mostly in French, was translated into English by one very brave soul, David Wharry. I have worked with both French and English copies of the catalogue before me, finding relatively few errors in translation, imagining poor Wharry being urged to hurry and get this catalogue out in time for the opening. He faced hundreds of pages of text liberally sprinkled with photographs of many works by both artists-some of them well known, some not previously exhibited. Indeed, some had been left unfinished by the creators. The most obvious pairs, of course, we can assume were created by Camille Claudel and Auguste Rodin working side by side from the same pose of the same model. But there 
are many, many other parallels and comparisons noted here, including other artists' work thoughtfully brought to our attention.

I was delighted to meet again some of my favorite commentators from earlier books and catalogues: Bruno Gaudichon and Anne Rivière, for example. Other earlier writers are frequently quoted throughout, of course. Our group of 14 names comes principally from France, Canada, and the United States. The key executive positions of this exhibit are also shared by the different sponsoring institutions. I found myself returning again and again to page 4 -in both catalogues the pagination is at least $98 \%$ exactly the same for every picture and every word. A reader could easily see from which country each author was writing.

Forty some "lenders" of objects in the exhibit are listed, including "all those who have wished to be anonymous."

The list of acknowledgments of people consulted must reach over a hundred individuals.

We are told that their planning for this collaboration began in 2001. To pull together this traveling exhibit and to publish the catalogue in two different languages by May 2005 must surely be a record of achievement.

Now let us look briefly at the individual entries in this very special catalogue. First, of course, we have a short preface co-signed by John R. Porter, from the Musée national des beaux-arts of Québec, and Jacques Vilain, Director of the Musée Rodin in Paris.

The introduction by Line Ouellet, from the Musée of Québec, sets the number of sculptures from Claudel and those from Rodin to be seen in this exhibit, noting that they are arranged in chronological order, marked by changes that occurred in the lives of the two artists, under such headings as "Before the Encounter", "Stormy Times", the "Freeing of Camille Claudel", and so on. Ouellet admits that they found all this organizing a "daunting undertaking (12)." She emphasizes that the general approach was "based on the research tools of art history [and] it deliberately avoids a psychoanalytical dimension that would emphasize family background, or even a feminist angle .... From the outset Camille Claudel had to fight for a foothold in the man's world of sculpture, 


\section{Claudel \& Rodin Fateful Encounter}

and would continue to do so throughout her career (13)." Ouellet also gives detailed examples of recent research efforts concerning Claudel and Rodin. Antoinette Le Normand-Romain, co-curator of this exhibit, is given special recognition as the writer of 9 of the 22 texts presented in the catalogue.

Now let's really start to walk through the chronological presentation of the catalogue as we look at the two sections of "I Before the Encounter". With the first section- "Claudel: The Early Works", written by Yves Lacasse-we find the formal referencing of traditional footnotes, wherein all the notes start on page 336 of the catalogue. The section itself goes over now familiar details of the Claudel family history, and gives many quotations from the Mathias Morhardt early article (1898) about Camille Claudel's achievements early on. Yves Lacasse gives a very recent look at how far Camille had come, before she met Rodin, in the mastery of sculpture. However, the precise dates of some of her early works still have not been settled. History is not always neatly recorded.

The following section is entitled "Rodin in 1882: On the Road to Success", written by Antoinette Le Normand-Romain, curator of sculpture at the Musee Rodin. She presents Rodin as on his way to success, on the way to being well known, but not all of the works that he submitted for exhibition were automatically accepted yet. The envious spread rumors that Rodin made casts of his models in order to create such realistic sculptures. Here we are also reminded that Rodin was already in a solid comfortable relationship with Rose Beuret, she who kept his clay properly damp for some twenty years. Moreover, Rodin had by now succeeded in getting an official commission to create a work in honor of Victor Hugo.

The next major section "II Happy Times (1882-1892)" begins with still another look at Rodin: "In Rodin's Studio", again by Le Normand-Romain. Le Normand-Romain continues with three more articles in this time period, followed by a single article each by Raphaël Masson and Bruno Gaudichon. Le NormandRomain focuses on aspects of Rodin's work, his relationship with 
Camille Claudel, and the blurring of the attributions of the works of the two artists. Masson deals with Camille Claudel as a portraitist, often using her family and friends as subjects. Gaudichon's article discusses the period noted for Claudel's portraits of young girls, perhaps all based on a single model.

The first of these "Happy Times" articles by Antoinette Le Normand-Romain is titled "In Rodin's Studio". We learn that in 1880 Rodin was given a large commission to do some decorative doors and was also given a studio which "became his principal workplace (37)." The doors were to be based on Dante's Divine Comedy. By 1882 there had appeared sets of plans for Rodin's Gates of Hell, which he himself referred to as a "grandiose work (37)." The status of Camille Claudel in Rodin's world at this time is not clear. There is the single name "Camille" listed after the names of Rodin's models in a studio record of this time. Was it Claudel? She might, Le Normand-Romain postulates, have already begun as his sole pupil, although she was still only an adolescent of 17 (40). At roughly the same period, Rodin had replaced Alfred Boucher as Camille Claudel's artistic mentor in her own studio (40). Camille Claudel was, of course, soon joined in work in Rodin's studio as well as in her own studio by other young women (see footnotes on p. 338 , including references to the 1898 Morhardt article). Herein is also described the addition of the Burghers of Calais group to the work of Rodin and Claudel (41). And we are told that Rodin began "exploiting" the figures of the Gates very early (43). Sometimes several versions of the same work originally by Rodin were turned out by other artists (copyists, in my perception) in his large factory-like studio (44). Sales of such items contributed to Rodin's wealth and his growing reputation for innovation. Even the more ordinary viewers of his work felt the impact of the muscular reality of his statues (49).

Antoinette Le Normand-Romain's next section, titled "Claudel or Rodin?", gives a crucial discussion of why accurate attribution of their work to one or the other is now hard, perhaps almost impossible, to achieve. Under the questioning title (66), we see photographs of four similar heads with open mouths; the first is 
labeled Rodin, the other three are labeled Claudel, their dates are all given as "about 1887"- the three by Claudel include question marks after the dates. There are five more heads on the following page (67). Some were in the Rodin museum, some were in the possession of the Claudel family. Le Normand-Romain herself despairs of reaching certainty: read this in its entirety for yourself. She is very honest when she avoids final attributions without clear evidence. Alas, we can't even be certain of the exact chronology of what we see. But surely it is in looking at Claudel's work in this period that we are faced with the fact of her presence as a creative artist equal to Rodin. (I went from the English version to the French, and back again several times, but I found them both swimming in uncertainty. I received a letter from Violaine Bonzon-Claudel dated June 7, 2006-she who oversees anything relating to Camille Claudel for the Claudel family. Mme BonzonClaudel expresses the hope that a fourth version of a catalogue raisonné will be out soon for Camille Claudel's work. Will more progress in regard to attributions be possible when this period is dealt with anew?)

The following subsection of "Happy Times", under the play-on-words heading of "Tête-à-Tête" also written by Antoinette Le Normand-Romain, contains a fascinating comparison of the efforts of Claudel and Rodin to portray each other as they seemed to each other in this period, especially through their sculptures. Rodin did several versions of Camille Claudel's head, begun when she worked beside him, then continued in different variations after she had left his studio to work in a studio of her own. In Le Normand-Romain's words, Rodin's work reflects his wish to portray "the woman he had loved so much (71)." As for Claudel's study of Rodin at this time, we are told, as could be expected, that she "in turn sculpted his portrait, a still young, thinfaced Rodin...(75)." This resulted in a prototype which came to be considered his official portrait. It was notably cast in bronze in 1892 , for which Rodin paid, and this was frequently presented along with exhibits of his work, from 1892 until 1902. Several medium-sized casts of this head of Rodin were also made, as well as 
still others of her versions of the head of Rodin. One of Camille Claudel's heads of Rodin ended up in San Francisco $(76,78)$, probably brought there through the efforts of Loie Fuller, the dancer who supplied Rodin's works to the private collection of a prominent San Francisco woman.

The next section of "Happy Times"_-Camille, My Beloved, in Spite of Everything"-(a quote from one of Rodin's letters to her), is also from the pen of Le Normand-Romain. We find several statues of couples by Rodin, obviously inspired by his passion for Camille Claudel, who was 24 years younger than he. Le Normand-Romain had presented a discussion of Camille's "fierce independence (75)" a few pages before the end of the previous section. But in Rodin's statues at this time we see his continuing fascination with Camille Claudel as a love object: take a look at the three of his sculptures entitled The Eternal Idol-a restrained approach, Eternal Spring-the beginning of a sweeping embrace by the man, and I Am Beautiful - the last of which shows the man holding her totally at his shoulder level, very high above the floor. Although not all of their dates are certain, Le Normand-Romain presents them in this order, which certainly seems to show Rodin's ever-increasing passion. Rodin's famous, well-known letter to Camille about the suffering she causes him is reproduced here, of course, and discussed, including the letter's probable reflection of her need to distance herself from him (84). Camille then took a trip to England and wrote to him from there; such letters as have been found are quoted. Included in this section as well is a separate one-page sort of contract which Rodin wrote and signed for her, guaranteeing that from October 12, 1886 on he will do many things, including declaring her status as his only pupil, and a promise that they will take a trip to Italy together, where she will become his wife, etc. (90). Moreover, in the so-called contract, Rodin promised to have a new photograph taken of her; this still exists today as evidence that at the beginning at least the promises began to come true. However, in regard to several sculptures to be finished (i.e. paid for by Rodin) and given to Camille, some ended up rather quickly in the hands of different individual collectors 


\section{Claudel \& Rodin Fateful Encounter}

(96-100). Le Normand-Romain is reduced to speculation here "... it also speaks volumes about the tensions reigning in the studio and one can imagine that at a given moment, in a fit of anger or due to lack of money, the two lovers parted with the works which were intended to seal their union (97)."

In short, "the year 1887 was also a difficult one for Camille ... (103)." Rodin's hopes for a trip together never materialized either. Camille had seriously quarreled with Jessie Lipscomb, who had shared Camille's first Paris studio. Next, Camille's time and energy turned to sculpting the legend of Sakuntala. Based on "a drama by the Hindu poet Kalidasa (103)," it would tell of a bewitched husband who had forgotten that he was married to Sakuntala. When his memory returns and he finds his wife again, he kneels before her and begs her forgiveness "which she trustingly gives him immediately (104)." This is one of Claudel's largest works-larger than life size, of course-and one that she worked on over a relatively long period of time. Antoinette Le NormandRomain treats us also to other lengthy comparisons with somewhat similar works by Rodin done in about the same time period: the Eternal Idol and the Kiss, for example. Claudel's head of a hooded woman, called the Psalm, seems echoed in Rodin's female head called Thought, which portrays Claudel herself (108). Le Normand-Romain even goes so far as to suggest that perhaps the respectful man in Rodin's Eternal Idol may be inspired by one of Claudel's supposed pregnancies at this time (109).

A work started soon after Sakuntala, the Waltz is introduced by Le Normand-Romain with the words "... now at the height of her powers, Claudel was capable of imbuing her works with great emotive power ... But she was also intent on asserting herself as an artist ... (110)." Gentle Reader, this whole section makes for fascinating reading indeed, coming as it does from a critic who works immersed in the midst of what I think of as the Rodin/Claudel Museum. Camille Claudel, in a letter to a friend "around 1891 (111)," emphasizes how much work she is expected to do on Rodin's works-in-progress, slowing down her own achievements. At about the same time, there was serious advice 
given to Claudel by governmental censors to put some clothing on her waltzers. She followed the somewhat prudish advice, producing a work of even greater beauty through several versions of graceful, swaying draperies.

The following section within "Happy Times" emphasizes Claudel's achievements as a portraitist during this rich period in her career. Raphaël Masson, Curator of the Archives at the Musée Rodin, writes "...Camille was not really considered a fashionable portraitist ... (129)." But she did considerable work in this vein, using friends and family members as models for sketches and paintings as well as many sculptures. Masson continues "Most critics agree that Camille's portraits have a life of their own... (131)." As Masson proceeds to give us many words of praise from contemporary viewers of her portraits, the catalogue gives us many convincing illustrations of a wide variety of her subjects. Masson's assessment of Rodin-as-portraitist compared to Claudel-as-portraitist is neatly summed up: "In contrast to the power and realism of Rodin's busts, sometimes stamped with a certain snapshot immobility, Camille Claudel's have a sense of the character and individuality of her models. It is perhaps in this domain that the two artists differed most... In addition to showing her talent, Camille Claudel, in each of her portraits, demonstrated a capacity to sculpt a soul behind a face. (133)."

The major division entitled "Happy Times" ends with "The Stays at l'Islette", written by Bruno Gaudichon, the Chief Curator at La Piscine-Musée d'Art et Industrie André-Diligent, Roubaix. Rodin and Claudel had already spent some time together in the Touraine area in July 1889; in 1891 they stayed together at l'Islette, a château where they were paying guests. "Camille Claudel regularly stayed there until at least 1893 (135-6)." Rodin, who was working now on his important Balzac project, did many of his studies for the project while he was here in 1890 and 1891. Correspondence still exists from both Rodin and Claudel concerning details of their holiday spirit while there. For instance: will Rodin please buy for her in Paris a small two piece bathing costume? It seems probable that it was during the summer of 1892 that 


\section{Claudel \& Rodin Fateful Encounter}

Claudel first had the landlady's granddaughter pose for the bust of a little girl (137). So while Rodin was consumed by his Balzac project, Camille Claudel circa 1892 began her series of portrait studies of a quintessential beautiful little girl. Soon thereafter in 1893, Camille would write her famous letter to her brother Paul concerning her plans for her work in the future, not at all like anything Rodin might do, said she. It was very clearly a compelling need for artistic independence that caused her new inspirations shown in several sketches in her letter.

There has also been much speculation among those who study Claudel's life and work as to the probability of her having had an abortion at this time. It seems very likely, since it was assumed so even by members of the Claudel family (140-146).

In quick succession now, Claudel prepared several of her recent works for various exhibits, and many were purchased for museums and by private international collectors of contemporary art. A counterpoint to the series of the Petites Chatelaines was Claudel's much admired bust of the little boy Charles Lhermitte. Claudel now indulged in producing many copies of her popular works as Rodin had long done with his (142-3). She also produced "a series of patinated plasters as a substitute for the more expensive bronze cast... (143)."

Gaudichon continues at length his examination of Claudel's success, especially in regard to her expanding development of the Petite Châtelaine series. He emphasizes her growing self-confidence as she attains a recognizable style of her own, noting that the critic Geoffroy was "extolling the independence that the younger artist had gained vis-à-vis Rodin's manner (148)."

Gaudichon ends his section with a long appreciation of Claudel's technical and thematic innovation during this period of great expansion of every aspect of her creativity. A reader should spend thoughtful time on these pages-while lingering over the beautiful photographs which accompany it.

Alas, we must then go on to "III Stormy Times (18921899)" which overlap the end of "Happy Times". This main division begins with a strangely titled section-"The Osteology of 
Old Women"-the study of the skeleton of old women. Here we return to the writing of Antoinette Le Normand-Romain, preceded by a photograph of the 1893 plaster version of Camille Claudel's statue of Clotho, the one of the fates known also as Clotho the Spinner, who spun the thread of life. More than one artist at the end of the $19^{\text {th }}$ century would portray this particular Fate or an old woman. By contrast with the others, says Le Normand-Romain, "As she had learned from Rodin, Camille pushed realism as far as possible, but far from dwelling on the sadness and decline that are the lot of advanced age, she transcends this and turns the hideous torso of the old woman ... into a 'Triumph of Old Age,' ... (153)." The stunning photos of the rear of the statue remind us that this should be on view at the Musée Rodin the next time we are there. In the same period both Jules Desbois and Rodin also did statues of skinny old women, probably using a common model. In 1895 money was raised so that Claudel could have her Clotho done in marble. Rodin contributed 1,000 francs. It was exhibited in 1899 by the Societé Nationale des Beaux-Arts. The statue was supposed to be given to the Musée du Luxemborg, but Claudel kept it for a while, until Rodin himself delivered it to the museum-which then refused it. The marble statue, alas, then disappeared, leaving only a couple of photographs to record it existence (165).

At the end of this section, Le Normand-Romain spells out the widening separation between Rodin and Claudel. Rodin moved into the dwelling of his longtime companion Rose, while Claudel-without yet breaking completely from Rodin-took separate quarters for herself. Rodin is seen as continuing to show his love for Camille in his work, whereas Camille begins to create her version of the story in her group of three known as the Age of Maturity (166).

The following section of the catalogue declares itself as "The Age of Maturity or Fate", and is written by John R. Porter of the Musée National des beaux-arts du Québec, and identified on p. 4 as the Initiator of the exhibition. Having first quoted from Louis Aragon "The future is what lies beyond the outstretched 
hand! (169)," Porter states firmly: "It is impossible to overestimate the importance of The Age of Maturity, the summit of Camille Claudel's art and supreme illustration of her genius (169)." As I write my one point perspective from the isolation of Wisconsin, I do not know whether Porter wrote first in English or in French, but the French text omits the word "supreme" (169 in both catalogues). Ah, the mysterious ways of translation ... In any case,

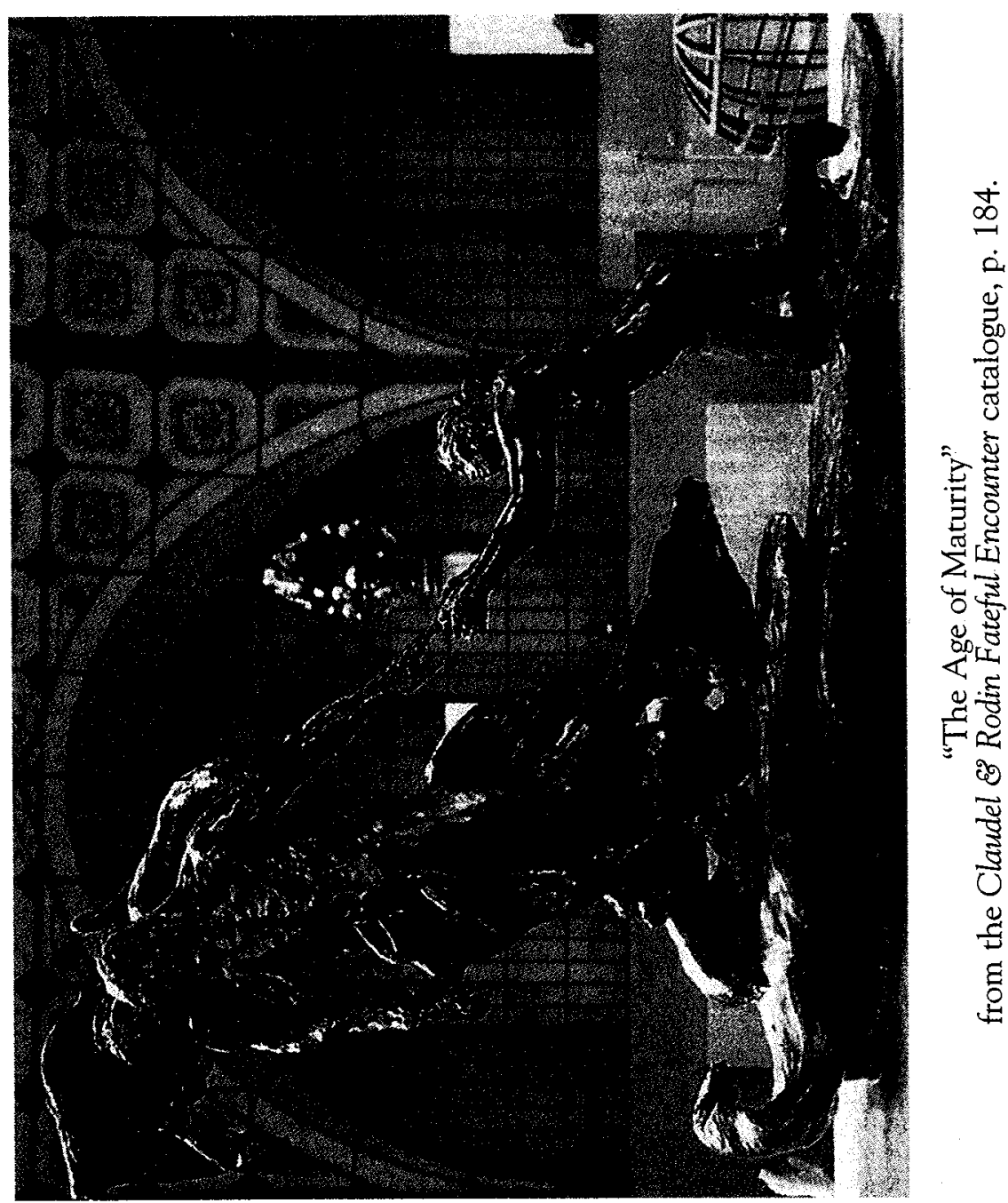


Porter makes crystal clear his belief that this work is the "encounter of two destinies, or more exactly, the separation of two destinies... [It] is the ages of life which passes and that, one day, confronts us with the unanswerable (169)." Porter discusses at some length the "protracted break-up" which lasted from the first showing of this group in 1892 until 1899 (169). It is conceded that after the breakup, Rodin tried to help Camille Claudel from a distance in matters of money, sales of her work, etc. The critic, Morhardt, and his wife extended more personal attention to her (171). Claudel's desire to keep Rodin at a distance in order not to be accused of always taking his advice is also cited (173-5).

The Age of Maturity presents Old Age/an Old Woman pulling a mature man away from an imploring, kneeling woman, both young and beautiful/Camille herself.

Let me quote at length here from Porter: “... it is entirely understandable that she should have insisted on being allowed to develop the Age of Maturity in complete secrecy, far from Rodin's eyes, since its very subject was guaranteed to annoy the great man, who persisted in wanting to protect and help her. Camille's aim [... $\mid$ was therefore twofold: on the one hand to realize her most ambitious work as a way of asserting her own genius loud and clear, a genius distinct from Rodin's, and on the other to publicly unveil her former relationship with Rodin and denounce the fact that he had in the end preferred his old mistress, Rose (176-7)." Porter then spends much time and space under his title The Genesis of the Work: we are given many details from a letter which Camille wrote to her brother Paul, including a post scriptum which seems to reveal signs of paranoia as she warns Paul not to tell anyone about all this. And you can also read here the account of early showings of the statue of the kneeling young woman alone, as well as a first version of the group of three which Porter describes as "overly narrative (177)." Varied reactions of several contemporary critics are to be read as well. They are not all flattering - stormy times, indeed. Porter mentions the concurrent nasty sketches which Claudel had sent in a letter to Rodin (discussed at more length in a following section of this catalogue by Jacques Vilain) 


\section{Claudel \& Rodin Fateful Encounter}

and on a more serious level, the efforts of the official governmental art staff to award an official (paid) commission to Claudel-perhaps for the group of three. The official assessment remains for us to read: "... it really is a very noble and very advanced work for a woman (180)." Sans commentaire ...

Porter presents at some length, covering several years, the official reports on Claudel's progress with the Age of Maturity which were written by a state inspector named Silvestre. In 1896 Silvestre recommended that she receive some payment for her work. Two and a half years later, Claudel announced that the work was finished. On November 1, 1898 Silvestre, after mentioning some modifications made by Claudel, wrote "... it deserves the bronze cast which the artist requests... (180)." Then Porter specifically ties at least some of the cause of Camille Claudel's breakdown to this particular work of art, saying: "After five years of effort .... The Age of Maturity was indeed an act of artistic selfassertion on Camille's part, but this was done at the price of emotional overload. On a human level, Camille was more fragile than ever (181)." Porter speculates that Rodin probably influenced the lack of follow-through on Camille's government commission for this group; its rendering in bronze or marble was cancelled (183-4). Many of the men who had admired her work-including Rodin - did try to help her still. But it was a not very wealthy soldier named Tissier who succeeded in having the group cast in bronze for himself. It remained in the Tissier family until it was bought by the Musée d'Orsay in 1982 (184). When this was exhibited early on, there were still those who could see it only as another work influenced by Rodin" "... something of a caricature of Rodin's genius (186)." Still, Camille Claudel did have strong supporters in the critic Charles Morice and most importantly in Eugène Blot-art dealer, foundry owner (!), publisher, and the treasurer of the Société des Amis du Musée du Luxembourg. In 1903 or 1904 Blot acquired rights of reproduction especially of her Age of Maturity. Read this text for details of exhibits of her work and the frequent glowing criticisms like that of Louis Vauxcelles (188). Indeed, Porter's massive evidence about what was happen- 
ing to Claudel and her work in her last years of freedom is so rich that I cannot hope to summarize it for you. Do read it-among other things you will be treated to Porter's view of Paul Claudel's sensitive and poetic appreciation of his sister's work (189-197).

The following short subsection by Jacques Vilain, Director of the Musée Rodin, titled "Camille Claudel: Vitriolic Caricatures" gives us photographs of the four drawings done by Camille in cartoon style plus a brief history of how they came into public view after 1982. Then we have the account of how they were ultimately solemnly attributed to Camille rather than to the never acknowledged son of Auguste Rodin and Rose Beuret. (He went by the name of Auguste Beuret.) The dating of the drawings has also received solemn examination. Vilain concludes simply "... she tells Rodin in a caustic way exactly what she thinks of him. The duality of Camille's character is expressing itself to the full (201)."

The chronological arrangement of both the Claudel-Rodin exhibit and this catalogue continues as Antoinette Le NormandRomain writes the next two subsections-Balzac and Camille Sublimated.

Rodin went through a long series of trials as he searched for a satisfactory-to-everyone statue of Balzac. This he did while at the same time he worked on the group known as the Burghers of Calais - and continued to juggle the production, marketing, and sales of his factory-like operation. It was also the period which was marked by his somewhat lengthy break-up with Camille. If he began these trial runs around 1892 , it was 1897 when he was finally content with one of his nudes of Balzac, developing a draped robe to cover the figure. (Midwesterners will remember seeing one of the nudes in Chicago.) It is Antoinette Le Normand-Romain who leads us through this slow process, supplying fascinating details of how Rodin picked a live model and eventually dressed it in a robe meant to resemble what Balzac wore when he wrote. The photographs of the various stages make a most graphic presentation of Rodin's thorough approach. Again I advise you to read this text, with its careful recreating of how Rodin and Camille came to 


\section{Claudel \& Rodin Fateful Encounter}

exchange letters-which still exist - and are quoted here-recording Camille's enthusiastic praise for the Balzac (205-210). The press and the public had a harder time accepting this very innovative work, which in effect hid Balzac's body. Le Normand-Romain writes, "... she immediately understood that Rodin's Balzac had turned over a new leaf in the history of sculpture ... (214)." The roar of misunderstanding from press and public caused a near scandal. But in the end, of course, Rodin's faith in his work and Camille's admiration of it have won.

Two chronologically ordered assessments finish the Stormy Times division: Camille Sublimated and Poetic Variations on Aurora.

For those of us who have tried to follow the unfolding story (since the 1980's) of the life and work of Camille Claudel, the section next presented by Antoinette Le Normand-Romain of the Musée Rodin expands what is now known about many of the dates and details. "Camille Sublimated" takes up the story after Rodin chose Rose Beuret in 1893 and after Camille had closed her door to him: "... her face continued to haunt him and he embarked on an admirable series of allegorical portraits in which he expressed his utter confusion [in French "son désarroi"] (217)." They have found a notebook in which Rodin wrote later, but probably before 1913 when she was put in a mental institution: "I remember the glory we had together...I consider you a divine woman....Divine character you exalted me to your level (217)."

We are told that there are two groups of rarely shown portraits, one based on a head with short hair, the other group based on a head with a bonnet. "The former are more dramatic [... in the latter she becomes a kind of ... distant muse (217)." There are fascinating details of Le Normand-Romain's efforts to date many of these works by Rodin, accompanied by beautiful photographs. Another development was Rodin's use of Camille's face more than once to represent the spirit of France itself (216-231). A haunting face indeed.

Véronique Gautherin, identified as Formerly Assistant Curator, Musée Bourdelle, Paris, has the last brief offering under 
"Stormy Times". Antoine Bourdelle was an assistant in Rodin's studio from the early 1890's until at least 1898. Bourdelle became a friend of Camille, but from some short letters that passed between them dealing with Bourdelle's assistance in the sale of some of her works, they do not seem to have been close friends. Also still in existence, created or attempted to be written by Bourdelle was a sonnet titled Aurora, the title of one of Rodin's portraits of Camille. The first sonnet was attempted around 1898; leaving no new detail left behind, Gautherin presents us with evidence that in 1926 Bourdelle "felt compelled to rewrite this sonnet twelve times (233)." Gautherin tells us that this marble portrait of Camille "was never exhibited or reproduced during Rodin's lifetime ... (233)." But it inspired one artist to write sonnets!

At last we come to section IV "The Freeing of Camille Claudel 1895-1905". The first entry by Laure de Margerie, Researcher, Museé d'Orsay, Paris is titled The "Sketches from Nature" (in French "croquis d'après nature"). Around 1895 Camille Claudel had started calling many of her works "sketches from nature." (237) The passage of time since then has led art historians to file under this rubric many of Camille's new creations which differ in subject matter (everyday life) in size (many are quite small), materials (onyx, for example), in ethnic sources (Japanese/Oriental), and so on. Her famous letter to Paul about her plans and Paul's later written studies of her work are thoughtfully examined—and merit our close reading. Rodin's innovations had already been frequently admired; now Laure de Margerie claims similar praise for Camille Claudel. "... the modernism of Les Causeuses and The Wave is undeniable. Camille was using a new language, just as her brother Paul was using a new kind of metrics in his poetry (249)."

The following section under the division dealing with the "Freeing of Camille Claudel" is titled "A. Patron: Countess de Maigret" and is written by Anne Rivière, identified in this catalogue's list of authors simply as an art historian. Rivière wrote one of the first serious studies of Camille Claudel's life and work, L'Interdite: Camille Claudel, 1864-1943, Paris. 1983. (I no longer 
have my copy at hand, alas. Nor other books which followed, such as that of Reine-Marie Paris. See Special Collections in the Memorial Library of the University of Wisconsin in Madison, Wisconsin, USA.) In this part of Camille's history, Rivière brings us to a new period in Camille Claudel's life. She is trying to make her way in the French art world without the constant presence (and often the support) of Rodin. Rivière says that by 1897 Camille had met the wealthy widowed Countess de Maigret, who became Camille's patron until her death in 1910. Works by Camille Claudel which were in Mme de Maigret's home in Paris were sold by the heirs in 1913. Morhardt's famous 1898 article speaks of the Perseus and the Gorgon statue being finished for Mme de Maigret as he was writing. In this period, when Camille was around the age of 35 , she was preparing a marble Perseus for Mme de Maigret, another white marble Perseus for the Baron de Rothschild and a small pink marble Fireside Dream statuette for Mme de Maigret. No wonder that Camille wrote a letter saying that she was "tired to the point of hopelessness" and turned some of the marble work over to a lesser artist Pompon and his assistants (252). They would also complete the Wave in 1900 (252). We are told that Rodin probably helped pay for some of this work, and that Rodin "continued to help Camille at least until 1906 (252)." (With every date from now on, I remember that she will be put in an institution in 1913.) Although Pompon and his assistants did much of the work, there is evidence (in letters and notes by others) that Camille was there closely supervising what they did. When the finished work was shown in 1902 by the Société Nationale des Beaux-Arts, it received varied reviews by friends and foes. As usual, there are excellent photographs of several versions, including one well known early photograph of Camille standing behind her own head used as the Gorgon - with identical profiles (254-5).

Rivière includes many details about the versions and owners of much of Claudel's last years at work. Countess de Maigret was both commissioning new works and acquiring previous ones, for example the marble version of Sakuntala, known as Vertumnus and Pomona (256). Rivière also believes that Mme de Maigret and 
Camille Claudel had some sort of a falling out, perhaps in 1905, since after that there is no evidence of any more purchase of Claudel's work. Rivière's final paragraph sums up such achievements as resulted from the patronage of Mme de Maigret: the portraits done of Maigret family members show that Claudel was catering to what her client expected of a society portrait .... "These portraits are also extremely interesting in that they are among Camille Claude's few original works after 1898 .... By enabling the artist to prove her talent once more when her inspiration was running out, Madame de Maigret ... was certainly one of her most important mainstays during the last years of her artistic life (259)." (What I have omitted here is a long account of how Claudel reworked much of her earlier work. It seems to me that Rodin and others too sometimes reworked things?)

The final section of "The Freeing of Camille Claudel" reminds me that I find that I prefer not to dwell on the declining fortunes of any human being. So I may try to skim over what we have within "Take this helping hand I am holding out to you," Eugène Blot From Bronze Founder to Art Dealer," written by Catherine Chevillot, Head of Research, Documentation and Library Services, Musée d'Orsay, Paris.

The section on Eugène Blot and his relationship to Camille Claudel adds a great deal to our knowledge of what he tried to do for her as her career was shutting down. He was not an ordinary "fondeur." His father had begun the business; Eugène expanded it into being a dealer in art as well. In French he is called a "marchand." During what may be called her second creative period, he remained on very friendly terms with her-"une relation très chaleureuse." He was "the only person to have sought to produce editions of her work (261)." He did not stop at just pouring the bronze! And he was one of the first in France to offer limited editions of works of art, rather than mass production (262). Blot seems to have had a personal preference for paintings, but he also produced sculptures by Rodin, Maillol, and others as well as those by Claudel (262). But Blot himself felt that he had not really succeeded with the selling of his limited editions (263). Blot wrote her 


\section{Claudel \& Rodin Fateful Encounter}

a long reminiscing letter in 1932, when she had been institutionalized for nearly 20 years-regretting that he had not been able to sell more of her work (264). There were problems about what the rights to production of an artist's work were. After 1907 he acquired no new pieces, and after 1907 she produced no more (268). In 1913, of course, she was placed in an asylum. In 1937 Blot finally sold his so-called editions to Barbedienne. But the details of the sale were not then-nor since-clearly spelled out (269). There are many details given here on attempted research into these matters, but few firm conclusions. However, in regard to the personal relationship between Camille Claudel and Blot, Chevillot writes that he considered himself her friend, and "... she continued to hold him in high esteem as she did no other ... (271)." In a letter which Blot wrote to her in 1932, but which was never delivered to her, he called her a genius and said that he had never ceased to be her friend (272).

The last main section, dealing with Camille Claudel's work and life, begins with a quotation from a letter to her as its title: "He Never Loved Anyone but You". The first subsection, written again by Antoinette Le Normand-Romain, is titled "A Neobid wounded by an arrow". This begins with a long quote from a reporter's account of an interview with Claudel during her sculpting of la Niobide blessée - a figure of a woman alone in the position of that woman in the Sakuntala statue long ago. It is an obvious reworking of an earlier work, but it has a believable poignancy as it now suggests a dying woman. Le Normand-Romain emphasizes Claudel's enjoying her chance here to show how well she could handle her own work with marble-in contrast to Rodin's preference for turning his marbles over to assistants. We are also told that this particular statue had some popular success in 1905; Blot handled production and sales, often of smaller sizes. Claudel began in this period her habit of writing complaining letters about how badly Rodin had treated her, blaming him for her financial difficulties. There was another young man, ex-student of Rodin, who complained in similar fashion, so we have evidence here that she was not alone in this. Le Normand-Romain judges the Niobide 
statue, however, whose form is borrowed from past work, as "... a statement of defeat. Her career was over; never again would she who had received so much be capable of creating (285)." These are the final words in this section, which come after their author has discussed other reworkings from the same period: it is a piling up of facts, of course. For me, the works still have beauty in the midst of their creation-or non-creation?

Just before we are given a useful joint chronology of the lives and works of our two geniuses, Line Ouellet, Director of Exhibitions and Education, at the Musée national des beaux-arts du Québec, has the last official subsection: "Camille's Exile, Rodin's Glory". There will be three more entries called Studies, of which I will look at two.

The last chronological text in our catalogue is titled: "Camille's Exile, Rodin's Glory". It is begun with a full page photograph of Camille as she was aging. Most of us know this picture well. It too deserves the word haunting. There she is-wrapped in her dignity, no smile on her face. And why should she be expected to smile? The person taking the picture is the husband of her once close friend. They have come to pay her a rare visit. Her expression is at best enigmatic, her formerly strong and busy hands in repose. There is no trace left of the Camille who dressed so fashionably for the photographer hired by Rodin as he had promised when he had also promised to marry her. Now it is 1929 , she is 45 years old; she will live 14 years more. But I digress ...

Line Ouellet, Director of Exhibitions and Education at the Musée national des beaux-arts du Québec writes the text here. She begins with the heading "Camille and Paul", starting with 1905 when Camille made one of her last surviving works, the bust of Paul when he was 37 and she 40 . Ouellet writes well, a useful summing up even for us who know the details of the story already, of the support which Paul was to his sister at the time when each one of them was supposed to be recovering from an impetuous love affair. It was exactly then that Paul wrote his beautiful appreciation of Camille as an artist. This was published first as a separate article with the title "Camille Claudel, Statuaire." Ouellet's presentation 


\section{Claudel \& Rodin Fateful Encounter}

of how the lives of Claudel and Rodin eventually ended is well documented, of course, especially in this catalogue. You will want to read what is here at the very least. It will send you, if you like, to more complete documentation. I enjoyed Ouelett's close comparison of the difference between the funerals of Rodin and Camille Claudel-hers so simple and obscure, his about as massive as Paris can achieve. Ouellet concludes "... for Rodin life and art were one and the same thing. For both artists, creation was the sole thread running through their lives: for Camille, it let to exile, for Rodin, to glory (298)."

After an interesting charted chronology of the lives and works of both artists, we find a group of three unrelated-to-eachother and not chronological essays: 1) "Camille Claudel and Claude Debussy: a Friendship" 2) "Women Sculptors in Nineteenth-Century France" and 3) "Camille Claudel, 'A Woman of Genius'?" I will let you look at the second by Odile Ayral-Clause (from California-forgive my lack of precise documentation) as I make the briefest of references to the other two.

I salute whatever set of circumstances brought Jean-Michel Nectoux to the authorship of the short research article "Camille Claudel and Claude Debussy: a Friendship." Nectoux is listed as a Scientific advisor at the Institut National de l'Histoire de l'Art in Paris. I assume that it may have been Nectoux himself who knew where to look for more evidence concerning what went on between Claudel and Debussy. The romantics among us thought that there might have been a bit of romance. Nectoux says not so, but that the Waltz and the Flute Player may owe something to their friendship. They met in 1888-9. Camille was said to hate music-perhaps a result of having to listen to her sister Louise practice. As Nectoux takes a fresh look at the totality of the Robert Godet letters, he emphasizes the subject matter that Claudel and Debussy discussed, such as impressionism and the current new enthusiasm for Japanese art. Nectoux also emphasizes that Debussy would have seen many of Claudel's works in the homes of many of his friends. Godet has even indicated which of her works were Debussy's favorites. And, of course, we know that she gave him a 
copy of the Waltz for his own. Nectoux even imagines that the Waltz might have inspired Debussy's Two Arabesques ... which my one point perspective has me (Louise Witherell) now studying with my current piano teacher!

I shall not attempt to comment on the article which Odile Ayral-Clause has contributed to our catalogue. I have not really had the energy yet to absorb her recent book Camille Claudel: A Life (New York: Harry N. Abrams, 2002). I had begun my own small research into her subject matter-the life and work of women sculptors in $19^{\text {th }}$ century France-so I believe that she adds here some very useful background to the catalogue itself.

However, it is quite appropriate for me to look closely at the last essay: "Camille Claudel: 'A Woman of Genius'?" by MarieVictoire Nantet. She is listed on page 4-my much fingered page 4--of the catalogue as "Lecturer, Reims University, comparatist, editor of the Bulletin de la Société Paul Claudel. I have seen her and her mother, Paul Claudel's last child, Renée Nantet Claudel, at Brangues. Of course, I know the mother better for we are close in age. But, Gentle Readers, I can assure you that Marie-Victoire Nantet is a grandchild of Paul who must have the genes to produce a writer. Marie-Victoire Nantet's book L'Ombre du Roi (Paris: Stock, 1994), is one of my two favorite books in my small collection of books written by French women about their childhoods. Her title refers, of course, to Paul's presence in the family. Camille Claudel died soon after Marie-Victoire's birth, but since Claudel's growing family spent much of their summers together in Brangues at the château containing many of Camille's works, all of the grandchildren must have grown up knowing about Camille. Most recently, you can find a short introduction to the third augmented edition of Camille Claudel, catalogue raisonné, by Rivière, Gaudichon, and Ghanassia (Paris: Adam Biro, 2001), by this Nantet entitled "Camille Claudel à sa juste place."

In that excellent catalogue raisonné Marie-Victoire Nantet gives a beautiful, almost poetic summary of Camille Claudel's life and work, including the alternate risings and fallings of her reputation as a creative artist. Nantet gives great credit to the 
posthumous, unfinished-by-the-author book by Jacques Cassar, which was given the title Dossier Camille Claudel when it was published in 1987. Even though lacunae remain in the careful collection that Cassar made of evidence of all aspects of this artist's life, it is the solid base from which all subsequent supposition must begin. But Nantet also recognizes a tendency of those who study the material to personalize it, often to turn it into something mythical.

Some four years later in the Claudel $\mathcal{E}$ Rodin catalogue, we find Marie-Victoire Nantet is the author of the last of the "studies"- the last of the final miscellaneous essays.

To lead us into this finale, someone has chosen one of Camille Claudel's late plaster portraits-a self-portrait, no less, dated 1895-97. The photograph makes her appear almost expressionless-perhaps contemplative-in spite of an imaginative hairdo with leaves and flowers. Camille is just past 30 and seems to have put on a little weight. Nantet gives us then a quote from Diderot, included in a many-volumed editing of a Larousse dictionary published in 1892 , under the entry of "genius." "When nature creates a man of genius, she shakes her torch on his head and says: go forth and be unhappy! (325)" Nantet begins her own text with firm support for the genius of her great-aunt: "Camille Claudel most certainly was 'a woman of genius,' or 'a genius' as one says today, the shorter formulation giving the proposition more power, as well as occulting the mark of the female sex that for so long barred women from the artistic Olympus (325)" But almost immediately, Nantet asks all of the possibly negative questions that might be asked, intending to "query the artist's uncontested genius without stirring up a sterile debate (325)" Nantet then sets up her own plan of research on this subject by filtering succeeding comments by contemporary art critics through the contemporary Larousse Grand Universal Dictionary of the Nineteenth Century definitions of "genius" (326). So here is another occasion for us, Dear Readers, to admire some impressive piling up of research! Nantet anchors it all in the context of the late nineteenth century's standards. To read it all from page 325 through the end on page 335 may seem a bit long to some readers, but I believe that no one 
could have said it any better. It defies summary. You really must read it for yourselves. And then rejoice with me that the witness of this catalogue has come into your hands.

P.S. Permit me to thank those who have encouraged me in my efforts herein:

Debbie McCalister, Milwaukee, WI, faithful amanuensis; Annis Pratt, Birmingham, MI, who wrote at length after seeing the exhibit in Detroit, MI; Marie Bollinger Vogt, Sylvania, OH, artistic director of the Toledo Ballet, who shared The Toledo Museum experience when we were children, and who joined with Barbara Thierwechter, Perrysburg, $\mathrm{OH}$, to give me Claudel $\mathcal{G}$ Rodin (English); Elsa Honig Fine, Laverock, PA, editor, Woman's Art Journal, mentor and now a friend; Nina Hellerstein, Athens, GA, colleague and claudélienne; Sergio Villani, York University, Ontario, colleague and claudélien .

P.P.S. Please consult the Bulletin de la Société Paul Claudel 183 (Sept/Oct '06) for a final article by Lacasse (Québec) and Le Normand-Romain (Paris). 